\title{
Niklas Olsen
}

\section{Mellem Carl Schmitt og Martin Heidegger \\ - Reinhart Kosellecks søgen efter en historie- ontologi i kølvandet på Anden Verdenskrig}

"Da jeg kom ud af fangenskabet - da jeg i hvert fald stadig var påvirket af det - og læste Heidegger, opfattede jeg 'Sein und Zeit' som en slags 'Bæltespænde-Filosofi' (...). Jeg har lært lige så meget af den som af Deres 'Begriff des Politischen”". Sådan skrev den nu 81-årige tyske begrebshistoriker og historieteoretiker Reinhart Koselleck i et brev til Carl Schmitt i januar 1977. Brevet er et af i alt 53 hidtil uudforskede breve, som Koselleck skrev til Schmitt i perioden 1952-1983. ${ }^{1}$

Reinhart Koselleck har i snart 50 år virket som en fremtrædende og indflydelsesrig historiker i den tyske forskning. Med berømte værker indenfor bl.a. idéhistorie, socialhistorie, begrebshistorie samt historisk teori og metode er det kontinuerligt lykkedes Koselleck at lægge nye vinkler på modernitetens fremkomst og historiske bevidsthed, som er de store og gennemgående temaer $i$ hans videnskabelige produktion. Samtidig har Koselleck fra 1950erne og frem til i dag, hvor hans værker har opnået stor international anerkendelse, indtaget en position som outsider indenfor den tyske historieforskning. Dette skyldes bl.a. Kosellecks utraditionelle valg af emner og hans tilgang til disse. Med et fokus på bl.a. historisk tid, voldelig død og betingelserne for mulig historie og med brug af et varieret kildemateriale bl.a. bestående af malerier, nedskrevne drømme og krigsmonumenter skiller han sig markant ud blandt de tyske historikere.

Kosellecks position som outsider i den tyske historievidenskab er dog også betinget af hans stærke pessimisme i forhold til det moderne samfund, dets politik og dets videnskab: Koselleck er mistænksom over for enhver tale om samfundsmæssigt fremskridt; han har længe været ekstremt skeptisk over for politisk demokrati; og han tvivler stærkt på, at mennesket kan lære af eller forstå historien. Endelig er Kosellecks identitet som historiker og intellektuel 
utvivlsomt også et resultat af, at han fra slutningen af 1940'erne var elev af og i mere end 30 år plejede bekendtskab med Carl Schmitt. Faktisk bør Koselleck - med undtagelse af personer fra de politiske og juridiske videnskaber - anses som den fremmeste viderefører af Schmitts tanker og projekt, eller dele af dette, $\mathrm{i}$ tiden efter nazismen. Gennem hans forfatterskab kan man således lære en del om Schmitts relevans i denne periode (Olsen 2004).

Formålet med denne artikel er dobbelt. Med udgangspunkt i Kosellecks breve til Schmitt ønsker jeg at belyse nye sider af, hvordan Koselleck har udviklet sine berømte og unikke tanker om historie og historievidenskab i efterkrigstidens Tyskland samt tegne nye linier af virkningen af Schmitts idéer i tiden efter 1945. Kosellecks breve til Schmitt er en fremragende kilde til en sådan undersøgelse, eftersom Schmitt fra slutningen af 1940'erne og indtil starten af 1980erne fungerede som Kosellecks mentor og sparringspartner, med hvem Koselleck ikke blot diskuterede og testede videnskabelige spørgsmål og hypoteser, men til hvem Koselleck også betroede politiske holdninger og personlige oplevelser.

Artiklen søger mere specifikt at vise, hvordan mange af de centrale karakteristika i Kosellecks tanker om historie opstod som løsninger på specifikke videnskabelige og politiske kriser, som Koselleck følte på et personligt plan i starten af 1950’erne. Jeg vil således demonstrere, hvordan Koselleck i et forsøg på at løse disse kriser først med inspiration fra Schmitt - dekonstruerede den tyske historisme og derefter - inspireret af Heideggers Sein und Zeit- udviklede en særlig historie-ontologi, som skulle gøre ham i stand til at forstå fortiden, kritisere nutiden, og øve indflydelse på fremtiden.

\section{Tabere af Anden Verdenskrig: Koselleck og Schmitt modes $i$ Heidelberg}

Kosellecks første møde med Schmitt fandt sted i Heidelberg, hvor Koselleck i 1947 havde påbegyndt studier i bl.a. historie, sociologi, jura og teologi. Blandt Kosellecks lærere var så prominente navne som Karl Lövith, Hans-Georg Gadamer, Werner Conze og Johannes Kühn. Det var imidlertid Schmitt, der fik størst indflydelse på Kosellecks første værk Kritik und Krise. Koselleck mødte Schmitt gennem en række seminarer med den karismatiske sociolog Alfred Weber, som tiltrak en kreds af studerende, der - ligesom Koselleck - havde en speciel interesse i skyggesiderne af det moderne. Blandt disse studerende, hvoraf flere $\mathrm{i}$ disse år blev disciple af Schmitt, var bl.a. Hanno Kesting, Roman Schnur, Hans-Joachim Arndt og Nicolaus Sombart (Laak 1993: 186-188 og Koselleck 2003: 74-76).

Koselleck erindrer sit møde med Schmitt på følgende vis: 
Sjaldent har jeg fäet stillet så mange kloge sporgsmål, jeg har sjaldent fort så inspirerende samtaler som dengang. Jeg havde netop oversat Hobbes til mit doktorarbejde. Schmitt spurgte, hvad jeg da ville med Hobbes, og så udviklede jeg min tese: utopiens opståen af misforboldet til den politiske uansvarlighed $i$ det absolutistiske system. Han udspurgte mig målrettet og opmuntrede mig igen og igen til at holde fast ved min tese, som jeg fremlagde i tre kapitler i doktorarbejdet; jeg skulle ikke lade mig paivirke afprofessorer, der måtte mene, at man burde skrive endnu mere og om andet.(Koselleck 2003: 76)

Kosellecks umiddelbare fascination af Schmitt førte som antydet ovenfor til, at Schmitt blev Kosellecks uformelle vejleder og sparringspartner i arbejdet med Kritik und Krise, der blev indleveret som Kosellecks doktorarbejde i 1954 og publiceret i en revideret version i 1959 (1954, 1959). Mødet mellem de to resulterede desuden i et personligt bekendtskab, der bestod indtil Schmitts død. Årsagen til Kosellecks umiddelbare tætte tilknytning til Schmitt i 1950'erne skal formentlig ikke blot findes i den intellektuelle fascination men også i en fælles oplevelse af nederlag under og efter Anden Verdenskrig. ${ }^{2}$ Der kan således ikke herske tvivl om, at Kosellecks videnskabelige og erkendelsesmæssige interesser har været grundlæggende præget af de personlige oplevelser, han gjorde sig på østfronten, i russisk fangelejr og som oprydningsarbejder i Auschwitz, efter at han i 1941, da han var blot 18 år, meldte sig som frivillig i den tyske hær. Hans værker skal læses som en reaktion på disse oplevelser, og det er også i dette lys, at Kosellecks stærke pessimisme i forhold til det moderne samfund, dets politik og videnskab skal forstås (Olsen 2004).

Kritik und Krise repræsenterer "et forsøg på at undersøge de historiske baggrunde for nationalsocialismen" (Koselleck 1988: 1), og bogen afspejler Schmitts stærke tematiske, metodiske, teoretiske, stilistiske end endog politiske inspiration på Koselleck. Således præsenterede Koselleck sit værk som en analyse af "den samtidige verdenskrise, bestemt gennem den polære spænding mellem verdensmagterne Amerika og Rusland" (1959: 1). Krisen skyldtes, at kommunismen og liberalismen nægtede at accepterede 'det politiske', men i stedet som moralske og utopiske anlagte ideologier eller historiefilosofier konstant sigtede mod gensidig udryddelse. Ligesom Schmitt - bl.a. i Der Leviathan in der Staatslebre des Thomas Hobbes (1938), hvori Koselleck fandt mange af de centrale begreber til sin analyse ${ }^{3}$ - søgte Koselleck den historiske forklaring på undermineringen af 'det politiske' i oplysningstiden. Nærmere bestemt i den forskydning $\mathrm{i}$ forholdet mellem politik og moral, der fandt sted mellem det 16 . og det 17. århundredes borgerkrige og den franske revolution. 
Anmelderne af Kritik und Krise havde ingen problemer med at genkende 'ånden fra Schmitt' i Kosellecks modoplysnings- og antimodernistiske anlagte analyse (Kuhn 1961: 666). På den baggrund synes det naturligt, at Koselleck - udover flittigt at referere til Schmitts værker - i forordet skrev en personlig tak til Schmitt "for i samtaler at have stillet spørgsmål og hjulpet til at finde svar" (Koselleck 1959). Men hvad var det præcis, Koselleck fandt så brugbart i Schmitts tænkning i de tidlige 1950'ere? Kosellecks breve til Schmitt kaster nyt lys på dette spørgsmål.

Cirka halvdelen af Kosellecks breve til Schmitt - 26 ud af de 53 - blev skrevet indenfor et årti, fra 1952 til 1962. I disse breve følger vi Koselleck gennem 'die Heidelberger Promotionsmaschine' - som inkluderede mundtlige eksaminer ved Gadamer, Johannes Kühn og Ernst Forsthoff - og hans efterfølgende søgen efter en akademisk stilling. Senere - efter at Koselleck fik en stilling som assistent for Kühn i Heidelberg - hører vi om hans oplevelser og erfaringer som underviser og om hans forsøg på at udforme et nyt projekt, som endte med det socialhistoriske værk Preussen Zwischen Reform und Revolution (1967a). Efter Koselleck sikrede sig et professorat, først i Heidelberg og senere i Bielefeld, og formulerede en mere selvstændig intellektuel position, faldt frekvensen af hans brevskrivning til Schmitt. Vi hører således ikke meget om processerne, hvori Koselleck konceptualiserede sine projekter om historisk tid og politisk ikonografi.

Ét kraftfuldt brev skiller sig ud fra samlingen. Det drejer sig om Kosellecks allerførste brev, som består af fem tætskrevne sider, dateret d. 21. januar 1953, et par måneder inden Koselleck færdiggjorde sit doktorarbejde. Hvad, der adskiller dette brev fra de andre i samlingen, er ikke blot brevets passionerede og intense tone, som på meget direkte vis belyser Kosellecks intellektuelle tilstand i starten af 1950'erne. Det er desuden den til tider kaotiske måde, hvorpå Koselleck ikke blot foregreb men faktisk kraftfuldt udtrykte de fundamentale ontologiske og metodiske elementer, som har karakteriseret hans videnskabelige produktion fra 1960'erne til i dag. Som jeg vil vende tilbage til senere, tyder meget på, at Koselleck netop havde udviklet disse elementer, da han skrev brevet. Brevet bevidner efter alt at dømme et vigtigt skift eller en vigtig forandring i Kosellecks historiske tænkning, og det tilbyder vigtige spor til baggrundene for og karakteren af denne forandring. Den følgende analyse vil være fokuseret på dette brev. 


\section{Videnskabelig krise: historisme og vardirelativisme}

Koselleck startede brevet med at takke Schmitt for hans gæstfrihed under et nyligt besøg i Plettenberg og for Schmitts kontinuerlige engagement i hans arbejde, som Koselleck havde oplevet igen i forbindelse med besøget. "Det fylder mig med særlig taknemmelighed", skrev Koselleck, "at De er gået så grundigt ind på mit arbejde". Han forklarede derefter præcist, hvad det var, han fandt så brugbart i Schmitts tænkning:

Vanskelighederne ved at forbinde 'systematiske' og 'bistoriske' betragtningsmåder, hvorunder bistorien i så hoj grad lider nu - man kan bare tanke på adskillelsen af sociologi og historie! - star nu langt klarere for mig, og jeg er Dem taknemmelig for den strenge formaning om, at man for at afklare begrebernes betydning altid skal fore dem tilbage til deres specifikeke situation. Der ligger i denne ansats uden tvivl den eneste udvej for historievidenskaben, bvis den overhovedet skal gore sig forbåbninger om at bestä, ud af historismen, for så vidt man med den forstair videnskaben om 'vardiernes relativering'.

Med disse sætninger påbegyndte Koselleck en lang og sønderlemmende dekonstruktion af tysk historisme - den anti-normative, anti-begrebslige og forståelsesorienterede tilgang, som dominerede den tyske historieskrivning fra Leopold von Ranke i 1800-tallet indtil Gerhard Ritter i 1960'erne. Denne dekonstruktion var bygget op om den sammenføring mellem sociologi og historie i form af den begrebslige tilgang, som Koselleck beskrev i citatet ovenfor.

Relativiseringen af værdier bliver problematisk, forklarede Koselleck, når historikerens rolle isoleres i historieskrivningen. Det var præcist denne isolation, som fik bl.a. Friedrich Meinecke til at anskue "værdierne ... som egentlig 'i sig selv' bestående størrelser”. Koselleck pegede hermed på en fatal metodisk mangel indenfor historismen: i deres radikale forsøg på at historisere alle værdier glemte historisterne at historisere sig selv, og dermed førte de - mere eller mindre ubevidst - specifikke subjektive værdier ind i deres analyser. Det var denne metodiske mangel og konsekvenserne deraf, som Koselleck reflekterede over på den følgende halvanden side i brevet.

Kosellecks refleksioner var centreret omkring to specifikke emner, mellem hvilke han bevægede sig frem og tilbage. Først og fremmest pegede Koselleck på, at historismen også var et produkt af historien, og at dens specifikke opståen skulle findes i 17oo-tallets historiefilosofier (Kosellecks studieobjekt i Kritik und Krise). Han argumenterede dog ikke blot for, at historismen og de fleste andre moderne værdier havde deres rødder i 1700 -tallets historiefilosofier, men også for at de havde mistet deres gyldighed i takt med, at historien havde forandret sig. Deres originale mening tilhørte således en specifik historisk situation i det 18. århundrede. Tilbageførelsen af værdierne til en proces 
kendetegnet af kontinuerlig forandring, fortsatte Koselleck, er således “i høj grad historiefilosofisk forbelastet og specifikt ahistorisk, da den kun bliver mulig gennem et uendeligt flugtpunkt, der fortoner sig i fortiden".

For det andet omtalte Koselleck - dog ikke særlig eksplicit - de værdier, som historismen bar med sig fra det 18. århundrede ind i samtidige historiske analyser. Han skrev bl.a.: "Men disse tendenser og deres tilbageførsel til den historiske 'proces' $\ldots$ bundet til historiens linexre tidskonstruktion, hvis evidens er matematisk og historiefilosofisk." Med andre ord kunne historismens slægtskab med 1800-tallets historiefilosofier aflæses af dets lineære, samlede og progressive historieopfattelse. Koselleck behøvede ikke at gå i detaljer angående det farlige potentiale i en sådan opfattelse, idet hans analyse i Kritik. und Krise netop var fokuseret på oplysningstænkernes forsøg på at accelerere og beherske historien. Desuden var Koselleck utvivlsomt klar over, at Schmitt også havde kritiseret historismen på dette punkt. Det var bl.a. tilfældet i Schmitts Die Buribunken fra 1918, som var en parodi på og kritik af historismens tro på samfundsmæssig og videnskabeligt fremskridt i 1800-tallet - en kritik, Koselleck ca. 30 år senere trak på i artiklen Die Verzeitlichung der Utopie (1982). ${ }^{4}$

For Koselleck var moderniteten karakteriseret af den altid tilstedeværende mulighed for krise og krig, snarere end af kontinuerlig fremgang, og hans dom over historismen var utvetydig:

Den er et restprodukt, som manifesterer den borgerlige tankemådes vedvarende magt og ikke, som Meinecke mener, en genuin skabelse. Den er lige så lidt et svarpå vores situation, men snarere en del af denne situation, idet den ikke formair at satte situationen pà begreb, som den ellers bar til opgave.

Det var netop dette 'svar på vores situation', som Koselleck var på jagt efter i sit brev til Schmitt. Han fandt imidlertid ikke svaret i Schmitts værker. I stedet fandt han hos Schmitt en sociologisk, systematisk og 'realistisk' tænkemåde centreret omkring analyser af begreber ${ }^{5}$ som han kunne anvende til at fjerne den røg, der forhindrede ham $i$ at finde svaret. Denne røg var skabt af den teoretisk men også politisk naive og dermed farlige arv fra den tyske historisme, personificeret af Friedrich Meinecke og dennes berømte værk Die Idee der Staatsräson fra 1924. Schmitt, der tidligt viste sig som en nådesløs kritiker af den tyske historisme (Bendersky 1988), skrev i 1926 en yderst kritisk anmeldelse af dette værk (Schmitt 1940). Han havde bl.a. angrebet den i hans øjne ringe anvendelse af begreber og den primitive modsætning mellem magtpolitik og moral i Meineckes bog. Dette var ifølge Schmitt en modsætning, som retfær- 
diggjorde den tyske identitetsfilosofi og medførte en form for overlegenhed, der hvilede på et konstant skiftende synspunkt - en evig bevægelse frem og tilbage.

Hvor Schmitts kritik af Meineckes idealisme var fokuseret på det politiske spørgsmål 'Hvem beslutter', forsøgte Koselleck i sit brev til Schmitt at dekonstruere, hvad han opfattede som en forkert tilgang til studiet af historie: han ønskede kort sagt at radikalisere historismens projekt. Endnu et spor til inspirationen fra Schmitt i dette forsøg findes i en lang fodnote i den originale version af Kosellecks doktorarbejde. I denne fodnote skitserede Koselleck præcist, hvordan han opfattede forskellene mellem Schmitt og Meinecke. Han skrev bl.a.:

I modsatning til C. Schmitt, som altid klarlagger den historiske sammenhang mellem en andelig evidens og de tilhorende politiske og sociale strukturer, er det bistoriske bovedvark 'Idee der Staatsräson', som ombandler sporgsmålet om 'Moral und Politik', fuldkommen abistorisk $i$ sin ansats. (Koselleck 1954: 24, note 72) ${ }^{6}$

Ambitionen med Kritik und Krise var imidlertid at blotlægge den moderne verdens politiske rødder - ikke at dekonstruere historismen. Dette var imidlertid målet i Kosellecks brev til Schmitt fra januar 1953, men kun som et nødvendigt skridt i forsøget på at finde 'svaret på vores situation'. Hvad mente Koselleck med dette?

\section{'At trange igennem til en historie-ontologi': Heideggers tanker om 'Endlichkeit'}

For at imødegå historismens relativitet fremførte Koselleck i sit brev til Schmitt efterfølgende et radikalt forslag. Han skrev:

Man burde $i$ kraft af denne stadig meget historiografiske indsigt trange igennem til en bistorie-ontologi, som ikke blot er det sidste nye metodiske påfund, men begyndelsen på en begrebsdannelse, der gor det muligt at grave historiefilosofien op af vandet, og som dermed kan udgore et svar på vores konkrete situation.

Det var manglen på en sådan ontologi - og, som en konsekvens heraf, manglen på brugbare begreber - der forhindrede Koselleck i at opnå et 'sikkert greb' på sine studier. Selv om han fremhævede Hans Freyer for i Weltgeschichte Europas fra 1948 at have gjort en stor indsats i retning af at udvikle en brugbar ontologi, står det klart, at han fandt inspiration til sin ontologi andetsteds: 
Reduktionen af andelige ytringer til en given situation satter en absolut ende for yderligere relativeringer $i$ bvilken som belst retning. Det bistoriske menneskes 'Endlicbkeit' skal altsà sattes i fokus, ikke med henblik på det individuelle 'Dasein' ... men med henblik på historiens vedvarende tilblivelse: altså med henblik, på strukturerne i en situation, uden bvilken der ikke ville findes sådan noget som historie.

Det, Koselleck gjorde i disse sætninger, var gennem en selektiv læsning af Heideggers Sein und Zeit fra 1927, at etablere et basalt fundament for en historie-ontologi. Uden at kommentere direkte på bogens første del om 'Daseins' mening fokuserede Koselleck på den anden del om 'Daseins' historicitet. Det var heri, at Koselleck fandt Heideggers tanker om 'Endlichkeit', som Koselleck præsenterede som det brutale faktum, ingen relativitet kan overskride, og som den basale historiske antropologiske konstant, der skaber og konstituerer historie.

Eftersom mennesker ikke kan transcendere historien, forklarede Koselleck, gennemtrænges alle menneskelige ting af 'Endlichkeit', "som hele tiden stiller spørgsmål ved det historierum, som de enkelte mennesker tilhører". "Læren om denne 'Endlichkeit", konkluderede Koselleck således, "har som eskatologi også forrang indenfor historievidenskaben". Dette var imidlertid ikke tilstrækkeligt. For at etablere en bistorie-ontologi fandt han det nødvendigt at tilføje specifikke begreber til Heideggers tanker om 'Endlichkeit'. Umiddelbart efter at have tildelt 'Endlichkeit' den helt centrale plads i ontologien, skrev han: ''Herre og slave', 'ven' og fjende', 'kønslighed og generation' og alle 'geopolitiske' spørgsmål hører herunder. Heidegger har forbigået alle disse fænomener i sine eksistensanalyser i 'Sein und Zeit"'.

Via disse passager færdiggjorde Koselleck sit projekt med først at dekonstruere historismen for efterfølgende - med udgangspunkt i Heideggers tanker om 'Endlichkeit' og med anvendelse af grundlæggende begreber fra Schmitt, Hegel og Hobbes - at etablere en ontologi om, hvad der skaber og strukturerer historie. Det er indenfor denne ontologi, at Kosellecks historiske tænkning har bevæget sig lige siden, selv om han sjældent refererer direkte til Heidegger i sine tekster.

I et nyligt interview har Koselleck dog fremhævet Heideggers betydning for sin historiske tænkning: "Jeg har lært så meget af ham. Inspirationen til en historisk tidsteori skyldes også min lekture af 'Sein und Zeit"' (Koselleck 2003: 76). Hvad Koselleck refererer til, er det specifikke fokus på og forståelse af historisk tid, som har været i centrum af hans forskning siden de tidlige 1960'ere. Koselleck har mere specifikt i mere end 30 år kontinuerligt argumenteret for, at det, der konstituerer ikke blot individer men også grupper og samfund, er, hvordan de opfatter og forholder sig til deres egen temporalitet 
og - som en følge af den uundgåelige 'Endlichkeit - i særdeleshed deres fremtid. Det er med udgangspunkt i denne opfattelse, at Koselleck siden 1960'erne har hævdet, at moderniteten er karakteriseret af en forventning om konstant forandring og fremskridt (1967b), og at han siden 1970'erne har argumenteret for, at 'historiens tidslighed' bør være emnet for historievidenskaben; at denne netop skulle adskille sig selv fra andre videnskaber gennem en teori om historiske tider (1971).

Læsere af Koselleck værker vil således genkende, at Koselleck siden 1970erne har fremført 'Endlichkeit' og de øvrige begreber i hans ontologi i et forsøg på at imødegå historismens krise (2000b) samt på en række forskellige måder udforsket temaerne $\mathrm{i}$ ontologiens begreber $\mathrm{i}$ sine konkrete historiske analyser. Det finder man et interessant eksempel på i den provokerende men indtryksfulde og af Schmitt tydeligt inspirerede artikel Zur historisch-politische Semantik asymmetrischer Gegenbegriffe fra 1975 (2000c), som omhandler ven/fjendedikotomien. I artiklen demonstrerer Koselleck, hvordan de i oplysningstiden skabte begreber 'menneske' og 'menneskelighed' og deres modbegreber 'umenneske' og 'undermenneske' - i modsætning til de tidligere dikotomier såsom 'hellener/barbar' og 'kristen/hedning' - har undermineret muligheden for anerkendelse og gensidig respekt imellem politiske grupperinger.

Som en udvej på den moderne destruktive ideologisering af modbegreber henviser Koselleck i den bemærkelsesværdige slutning på artiklen til Schmitts ven/fjende-dikotomi. Det er Schmitts 'videnskabelige bedrift', bemærker Koselleck, med begrebsparret ven og fjende at have leveret en formalistisk politisk antitese uden på forhånd at fylde kategorierne i denne ud. Vil de stridende grupper freden, lyder Kosellecks pointe, kan den opnås ved, at man bruger Schmitts dikotomi på en gensidigt anerkendende og respektfuld måde. Det forekommer som et paradoks, at Koselleck gør sig til talsmand for en reflekteret og forsigtig omgang med begreber ved at anbefale en formaliseret brug af Schmitts ven/fjende-dikotomi. En dikotomi, Schmitt satte i nazisternes tjeneste, og som for mange fremstår som inkarnationen af ideologisering. Her berører vi imidlertid en af de væsentligste ligheder mellem Koselleck og Schmitt. Deres tænkning er grundlæggende struktureret omkring dette modsætningspar; opdelingen i venner og fjender anskues simpelthen som et grundvilkår for den menneskelige eksistens.

Læsere af Koselleck vil også genkende, at det var en videreudviklet version af Kosellecks historie-ontologi, som han præsenterede i sin tale i anledning af Hans-Georg Gadamers 85-års fødselsdag i 1985 med det formål at etablere en bistorik - "læren om betingelserne for mulig historie" (2000d). Med udgangspunkt i 'Endlichkeit' fremførte Koselleck 'Sterbenmüssen' [at skulle dø] og 'Totenkönnen' [evnen til at dræbe] som de første af fem begrebslige par, som 
ligger uden for sproget og muliggør samt strukturerer menneskelige relationer, organisation og historie. De andre par var ven og fjende, herre og slave, inde og ude (historisk rumlighed), mand og kvinde (generativitet). Således var denne ontologi stort set sammenfaldende med den, som Koselleck fremførte i brevet til Schmitt fra starten af 1953. Dengang var Koselleck imidlertid stadig i færd med at konstruere sin bistorik eller historie-ontologi. Det skete ikke kun som et svar på en krise indenfor historievidenskaben men også som et forsøg på at imødegå en specifik politisk krise.

\section{Politisk krise og historikerens rolle}

Direkte efter Koselleck præsenterede sin historie-ontologi, forklarede han Schmitt, hvilket formål ontologien skulle tjene. Dette formål var bestemt af den samtidige politiske krise. "Udgangspunktet for en historie-ontologisk analyse", skrev Koselleck, "skal, for ikke at forfalde til erkendelsesteoretisk resignation ..., og for ikke altid at starte hos egypterne, være den nuværende borgerkrig". Han forsatte:

Med de kategorier, som De, arede Professor, lagger til grund for Deres Nomos der Erde, lader sig $i$ hvert fald vise, at den herskende verdensborgerkrig ikeke er nogen ontisk eller kontingent begivenhed, der ikke burde vare (for amerikanerne), men en begivenhed, der helt igennem har sine rodder $i$ vores historiske varensstrukturer, men sä, hvis man iagttager disse strukturer, ikke bor vare sådan, som det er (for russerne).

Som bevidnet $\mathrm{i}$ disse passager - samt i såvel den upublicerede og publicerede udgave af Kritik und Krise - frygtede Koselleck en acceleration af den Kolde Krig i de tidlige 1950'ere. Ligesom Schmitt i sin Nomos der Erde fra 1950 opfattede Koselleck konfrontation mellem USA og Sovjetunionen som endnu en borgerkrig, men på en hidtil uset skala - en 'verdensborgerkrig'. Denne opfattelse delte Kosellecks to venner fra Heidelberg Hanno Kesting og Nicolaus Sombart, der også tematiserede begrebet verdensborgerkrig i deres samtidige doktorarbejder (Müller 2003: 104-114). Begrebet har i øvrigt fået en særlig plads i den tyske historiskrivning, efter at Ernst Nolte i 1970'erne og i 1980'ernes såkaldte tyske 'historiestrid' relancerede det med ny kraft men også tillagde det ny mening i sit forsøg på at forklare nationalsocialismens opståen og radikalisering som en reaktion på og som et værn mod kommunismen (Niethammer 1993: 52). 
I 1950'erne var Koselleck - også lig Schmitt - overbevist om, at verdensborgerkrigen udelukkende kunne blive forstået og imødegået gennem en blotlæggelse af dens historiske rødder. Dette fremgår af de efterfølgende linier i Kosellecks brev:

Sandheden ved en sådan historie-ontologi skulle lade sig paivise i enhver prognose, ligesom den på den anden side selv må have prognostisk. kraft, for så vidt de historiske tvangsprofetier kan sattes ud af kurs. (Om de har magt dertil, er en anden sag; men mere kan den 'bistoriske videnskab' ikke yde som videnskab.)

Koselleck tænkte således på historievidenskaben som en direkte praktisk videnskab. I en nøddeskal var hans mål med at studere fortiden at kritisere nutiden med henblik på at udøve indflydelse på fremtiden. Dette er præcist, hvad Koselleck har forsøgt gennem hele sin videnskabelige produktion, selv om de specifikke mål med Kosellecks analyser - som vi skal vende tilbage til - har forandret sig markant siden Kritik und Krise. Skrevet i en pessimistisk modoplysnings- og antimodernistisk tradition kan denne bog vanskeligt blive læst som andet end en konservativ bøn for en tilbagevenden til en stærk stat $i$ stil med den absolutte stat, som Schmitt tidligere havde advokeret for.

Koselleck og hans venner i Heidelberg opfattede Schmitt som en person, der besad indsigt $i$ alle fortidens bitre sandheder og realiteter, der var ved at blive udgrænset og glemt i de tyske sociale og humanistiske videnskaber efter 1945 med deres fokus på demokrati og genopdragelse (Laak 1993: 188). Den negative reception af Kritik und Krise resulterede i, at Koselleck blev en del af efterkrigstidens klub af stigmatiserede men $i$ hans øjne intellektuelt overlegne 'realister' (Olsen 2004: 41-43). Det er således svært ikke at tolke den måde, hvorpå Koselleck sluttede sit brev til Schmitt fra 21. januar 1953 som et forsøg på at kommunikere en følelse af delte bånd og skæbner de to imellem. Koselleck gjorde dette ved at citere Kants fortolkning af Job:

Job vardiger Gud, idet han isar viser ham det viise ved Hans skabelse ved at frembave dens undgrundelighed. Han lader ham kaste blikke på den skonne side af skabelsen ... men også på den afskrakkende side, idet han påkalder produkterne af Hans magt og derunder også de skadelige, frygtelige ting.

Til dette citat tilføjede Koselleck: "Jobs venner, der stræber mere efter de mægtiges gunst end efter sandheden, bliver ikke initierede". 


\section{Fra en undersogelse af den moderne verdens politiske rodder til en bistorie-ontologi}

Oprindelsen af Kosellecks historie-ontologi minder os om, at historieskrivning ofte bliver produceret i komplekse processer, som involverer både teori, personlige erfaringer og politik. Kosellecks historieskrivning, som den har udfoldet sig fra 1950'erne og indtil i dag, er således i høj grad formet af hans krigsoplevelser og hans efterfølgende møde med Schmitt og Heidegger. Lige som de fra starten af 1920'erne forsøgte at afdække det eksistentielle og reelle i forsøg på at løse specifikke spørgsmål og kriser indenfor politik og filosofi, forsøgte Koselleck med udgangspunkt i deres ideer at finde det eksistentielle og reelle indenfor historievidenskaben med det formål at løse samtidens erkendelsesmæssige og politiske krise i det delte tyske samfund.

Men i hvilken grad bevidner Kosellecks brev til Schmitt fra d. 21. januar 1953 et brud eller en forandring i Kosellecks historiske tænkning? I hvilken grad var de ideer, han præsenterede, et resultat af nye eller måske endda til en vis grad samtidige refleksioner?

To forhold indikerer, at Kosellecks ontologi var under udvikling, da han skrev brevet til Schmitt. Brevets intense tone og kaotiske struktur antyder kraftigt - som tidligere nævnt - at Koselleck kommunikerede tanker, som var helt nye. Vi må her huske på, at Koselleck præsenterede sine ideer umiddelbart efter at have takket Schmitt for igen at have udvist interesse for hans arbejde under hans nylige besøg i Plettenberg. Hvorfor skulle Koselleck, der på dette tidspunkt længe havde været en bekendt af Schmitt og nyligt havde diskuteret sit arbejde med ham, præsentere sine ideer på en sådan kraftfuld og presserende maner, hvis ikke disse var nye? Snarere end at Koselleck rekapitulerede velkendte argumenter fra tidligere samtaler, synes det sandsynligt, at Koselleck beskrev nye ideer - måske inspireret af besøget i Plettenberg?

For det andet er det værd at bemærke, at der kun er én uudviklet reference til Heidegger i Kritik und Krise (i den upublicerede version). Den findes i en fodnote, hvori Koselleck noterer ligheden mellem Hobbes og Heideggers forsøg på at konstruere formelle kategorier på basis af 'død'. Kosellecks konklusion: "En historie-ontologisk nyfortolkning kunne belyse og fordybe den fælles sammenhæng" (Koselleck 1954: 31, note 31) antyder, at Koselleck havde tid til at udvikle ideen tilstrækkeligt til at integrere den i værket.

Men hvis Koselleck i sit brev fra januar 1953 præsenterede Schmitt for en vigtig forandring $i$ sin historiske tænkning, trak han i en vis udstrækning på ideer og begreber, som han havde været bekendt med i længere tid. Således var opgøret med historismen - inspireret af Schmitts systematiske og sociologiske tænkemåde - i form af den metodiske tilgang til stede i Kritik und Krise uden dog at være et mål i sig selv. Desuden var Koselleck allerede bekendt 
med Heidegger fra slutningen af 1940'erne. Vi ved bl.a. fra det indledningsvist citerede brev fra januar 1977, at Koselleck allerede læste Sein und Zeit i sit tredje semester på universitetet. Opfattelsen af moderniteten i Kritik und Krise - som karakteriseret af et fokus på fremtiden og en konstant forventning om forandring og fremskridt - er formentlig et resultat af denne læsning. Meget tyder således på, at Koselleck i de tidlige 1950'ere arbejdede på to forskellige men også relaterede projekter, og det er endog sandsynligt, at det var hans undersøgelser af den moderne verdens politiske rødder, som fik ham til at føle et behov for en ny historie-ontologi.

Yderligere undersøgelser af både kilder og publiceret materiale er nødvendige for at belyse dette emne mere dybdegående. En foreløbig konklusion må lyde, at Kosellecks brev til Schmitt bevidner hvis ikke et skift så en forandring i Kosellecks historiske tænkning. I konstruktionen af sin historie-ontologi trak Koselleck tilsyneladende på bøger og ideer, som han længe havde været bekendt med. Samtidig tillagde han disse afgørende ny mening og forbandt dem på nye måder.

\section{Schmitt og Heidegger: Vennen og skolemesteren}

Oprindelsen af Kosellecks ontologi minder os desuden om, at historikeren møder og omgås sine inspirationskilder og deres ideer på meget forskellige måder - såvel intellektuelt som personligt.

I intellektuel henseende har Koselleck kun ladet sig inspirere af Heideggers tidlige værk Sein und Zeit. Eftersom Koselleck interesserer sig for den menneskelige selvforståelse og bevidsthed, ville det være forkert at reducere ham til decideret Heideggerianer. I forlængelse heraf synes Kosellecks personlige relationer til Heidegger at have været meget formelle. I det tidligere citerede brev til Schmitt fra januar 1977, hvori Koselleck refererer til sin forste læsning af Sein und Zeit, fortæller han Schmitt om sit møde med Heidegger i Gadamers seminarer ved universitetet i Heidelberg. Selv om han tydeligvis er dybt imponeret af Heidegger, omtaler Koselleck også, i en underspillet ironisk tone, "Heideggers skolemester facon". "Jeg har aldrig taget den gamle fra bjerget det ilde op", tilføjede Koselleck, "for det var jo netop meget 'belærende". Denne tone finder man også i det (tidligere citerede) interview, hvori Koselleck omtaler seminarerne i Heidelberg som sin "lekture af 'Sein und Zeit".

Det var i den samme ironiske tone, at Koselleck i brevet fra januar 1977 omtalte Heideggers Sein und Seit som en 'bæltespændefilosofi'. Koselleck refererede her til et bestemt bæltespænde, nemlig et 'Koppelschloss', som var de tyske soldaters bæltespænde. Dermed spillede Koselleck for det første på Sein und Zeit's bekendelse til Første Verdenskrigs krigsethos. For det andet gjorde 
han grin med begrebsparret i titlen: 'und' er således selve spændet, der let måske for let presser Heideggers krævende og måske ikke fuldt ud overbevisende filosofi bestående af 'sein' og 'zeit' sammen. Således har Koselleck udtrykt reservation overfor både den militære konnotation og argumentationen i Heideggers værk. ${ }^{8}$

Årsagen til Kosellecks faglige distance til Heidegger er ikke helt klar. Måske følte og føler Koselleck sig - ligesom sin mentor Schmitt, der de åbenlyse paralleller til trods heller ikke havde tætte relationer til Heidegger - forpligtet på en langt mere konkret tænkemåde, der efter hans mening ikke tillader samme frihed/udtryksform, som filosoffer benytter sig af. Det er tilmed sandsynligt, at Koselleck på linje med Schmitt tilmed betragter "kernen i al filosofi som politisk ideologi", som Reinhard Mehring skriver i sin artikel her i nummeret. Således udtalte Koselleck i det føromtalte interview, at han fra første læsning opfattede Heideggers filosofi som en nazi-filosofi.

Selv om Schmitts støtte til nazismen var langt mere konsekvent end Heideggers, har Koselleck aldrig udtrykt nogen form for personlig eller politisk distance til Schmitt. Dette skyldes utvivlsomt, at Koselleck ikke blot intellektuelt men også personligt var langt tættere knyttet til Schmitt. Hvor Kosellecks reception af Heidegger er bundet til en meget selektiv læsning af én tekst og brug af ét begreb, kan Kosellecks forfatterskab læses som en konstant dialog med en hel række af Schmitts tekster og ideer. Siden 1950'erne har Koselleck modificeret og nedtonet sin brug af Schmitt i sin historieskrivning. Det første skridt blev - som påvist - taget i starten af 1953, hvor Koselleck med Heidegger læste Hobbes antropologisk og dermed udvidede Schmitts Der Leviathan in der Staatslebre des Thomas Hobbes i filosofisk henseende.

Et andet skridt blev taget i arbejdet med opslagsværket Geschichtliche Grundbegriffe (Brunner m.fl. 1972-1997), hvor Koselleck har distanceret sig fra Schmitts begrebspolitiske hensigt. Koselleck anerkender på linie med Schmitt totaliteten af 'det politiske'. Men med et blik på begrebers farlige potentiale har han i sine begrebshistoriske undersøgelser kontinuerligt kritiseret og forsøgt at modvirke ideologiseringen af de politiske begreber (Mehring 2005).

Kosellecks modificering og nedtoning af Schmitt tog en yderligere drejning i starten af 1970'erne, hvor Koselleck flyttede sit videnskabelige fokus fra at forklare den historiske baggrund for modernitetens opkomst - og i særdeleshed Anden Verdenskrig - til at belyse menneskets historiske bevidsthed. Koselleck undersøger med andre ord, hvordan disse begivenheder er blevet forstået, bearbejdet og forvaltet. I løbet af denne proces er Koselleck intellektuelt gået nye veje og desuden fjernet sig fra sin politiske identifikation med Schmitt. Det mest slående bevis herpå finder man i Kosellecks engagement i den tyske debat om Holocaust-monumenter i 1990'erne - et engagement, 
som udsprang af Kosellecks arbejde med monumenter for faldne i krig (1979), og som ledte ham til at kritisere de overlevendes konstante forsøg på at politisere disse monumenter.

I forlængelse heraf udtrykte Koselleck i 1990'ernes debat om krigsmonumenter i en række skarpe indlæg en fundamental kritik af regeringens forsøg på at fremtvinge en politisk forhastet beslutning og argumenterede for, at kun en åben og offentlig diskussion vil føre til de bedste argumenter og dermed den mest hensigtsmæssige forvaltning af erfaringerne af krigen (Olsen 2004: 57-59). Faktisk tog flere af Kosellecks indlæg form af direkte opgør med Schmitts kritik af liberalismen, som Koselleck havde støttet op om i Kritik und Krise. Det gælder bl.a. artiklen Die Falsche Ungeduld fra marts 1998, der var udformet som en ironisk polemik mod Schmitts decisionisme. Heri skrev Koselleck bl.a.:

Der er blevet talt nok, nu må der besluttes. Sådan lyder parolen i forsoget på at få opfort det såkaldte Holocaust-monument. Det er for sent, nu kan der kun bandles. Dette pludseligt anvendte argument i forsoget på at undgå den fornyede og stigende debat om det planlagte mindesmarke er ligeså farlig som alle de balve sandheder, der bliver udstukeket. Naturligvis skal der besluttes, men ikke for der er blevet talt nok. (1998)

Kosellecks publicerede værker antyder, at denne ændring i Kosellecks historiske og politiske tænkning - som repræsenterer en ny måde at tackle, bearbejde og forsone sig med "egne lidelseserfaringer og den selvoplevede skræk" (Graf 1999) under krigen - skete mere gradvist end det skift, der fandt sted i Kosellecks historiske tænkning i starten af 1950'erne. Kosellecks breve til Schmitt bekræfter $i$ en vis grad denne tese. Ingen af disse breve belyser i stil med brevet fra januar 1953 de overordnede ontologiske, metodiske, emnemæssige og politiske temaer i Kosellecks videnskabelige produktion. Brevene belyser imidlertid en række andre interessante aspekter af, hvordan Koselleck tænkte om fortiden, nutiden og fremtiden - om historie, politik og personlige erfaringer - i perioden mellem 1950'erne og 1980'erne. 


\section{Noter}

${ }^{1}$ Kosellecks breve opbevares i Schmitts arkiv i Hauptstaatsarchiv Düsseldorf (under registreringsnummeret RW 265). Det ovenfor citerede brev bærer nummeret RW 2658172. Jeg vil gerne takke Reinhart Koselleck for at have givet mig adgang til brevene. Analysen af disse er begrænset af to metodiske problemer. Det er først og fremmest svært at sige, hvorvidt de 53 breve repræsenterer alle de breve, som Koselleck skrev til Schmitt, eller om Schmitt af en eller anden årsag har frasorteret nogle af brevene. At Schmitts breve til Koselleck (endnu) ikke er tilgængelige sætter for det andet grænser for fortolkningen af Kosellecks breve, og gør det umuligt at forstå og rekonstruere den dialogiske karakter af brevudvekslingen mellem Schmitt og Koselleck.

${ }^{2}$ Schmitt forsøgte bl.a. at bearbejde sit personlige nederlag i Ex Captitave Salus fra 1950, hvori han stillede spørgsmålstegn ved, hvorvidt historien skrives af 'sejrherren' eller den 'besejrede'. Koselleck videreudviklede senere Schmitts refleksioner til en historik, der bygger på, at taberne som en følge af deres trykkende erfaringer er i stand til at udvikle nye metodiske greb og dermed opnå ny indsigt i historien (2000a: 75-77).

${ }^{3}$ Koselleck overtog dog ikke den stærke antisemitisme i Schmitts værk.

${ }^{4}$ Koselleck anvendte Schmitts tekst som den ene af to tekster i sin advarsel mod, hvad utopisk tænkning kan føre til. Koselleck sluttede sin artikel med ordene: »Carl Schmitts utopi gik trods dens advarende funktion ... i opfyldelse, men værre end parodieret«.

${ }^{5}$ Koselleck har i et senere interview omtalt Schmitts begrebshistorie som "metodisk brilliant” og understreget Schmitts indflydelse på sit eget arbejde. Det var på opfordring af Schmitt, fortæller Koselleck, at han i arbejdet med Kritik und Krise fik interessen for via leksika og opslagsbøger at underkaste centrale politiske og sociale begreber historiske analyser (Dipper 1998: 188). En glimrende analyse af lighederne og forskellene mellem Kosellecks og Schmitts begrebsanalyser findes i Mehring 2005.

${ }^{6}$ Fodnoten er slettet i den publicerede version. Det samme er referencen til Schmitts kritik af Meinecke i litteraturlisten. I den publicerede udgave skriver Koselleck om den metodiske tilgang: »Den anvendte analyse forbinder altså idehistoriske analyser med sociologiske betingelsesanalyser« (1959: 4).

${ }^{7}$ Dette var en af flere passager med religiøse konnotationer i Kosellecks brev. Udover at ville give 'Endlichkeit' forrang som eskatologi i historievidenskaben skrev han andetsteds, at 'Endlichkeit' i denne sammenhæng ikke skulle fortolkes som »en fjern grænse, ved hvilken 'totalhistorien' engang ville tage sin ende (og til hvilken historikeren nu samler sine 'grænseerfaringer)' «. Disse passager er svære at fortolke men leder tankerne hen på den religiøse og apokalyptiske tone, som blev anvendt af mange tyske intellektuelle efter 1945.

${ }^{8}$ Jeg vil gerne takke Reinhard Mehring for disse oplysninger. 


\section{Referencer}

Bendersky, Joseph W. (1988). "Politische Romantik: Intellectual Critique and Enduring Scholarly Influence", Complexio Oppositorium - Über Carl Schmitt, Helmut Quaritsch (red.), Duncker \& Humblot, Berlin, s. 465-490

Brunner Otto, Wener Conze og Reinhart Koselleck (1972-1997). Geschichtliche Grundbegriffe. Historischen Lexicon zur politisch-sozialen Sprache in Deutschland, bd. I-VIII, Ernst Klett, Stuttgart

Dipper, Christoph (1998). "Reinhart Koselleck im Gespräch mit Christoph Dipper", Neue politische Literatur, nr. 2, s. 188-210

Graf, Friedrich Wilhelm (1999). "Die Macht den Schicksal Entschuldigt gar Nichts", Frankfurter Allgemeine Zeitung, 1/11

Koselleck, R. (1954). Kritik und Krise. Eine Untersuchung der Politischen Funktion des dualistischen Weltbildes im 18 Jabrbundert, Heidelberg

Koselleck, R. (1959). Kritik und Krise. Ein Beitrag zur Pathogenese der Bürgerlichen Welt, Karl Albes, Freiburg

Koselleck, R. (1967a). Preussen Zwischen Reform und Revolution. Allgemeines Landrecht, Verwaltung und soziale Bewegung von 1791 bis 1848, Ernst Klett, Stuttgart

Koselleck, R. (1967b). "Richtlinien für das Lexikon politisch-sozialer Begriffe der Neuzeit", Archiv für Begriffsgeschichte, bd. XI, s. 81-97

Koselleck, R. (1971). "Wozu noch Historie“, Historische Zeitschrift, 1971, bd. 212, s. 1-18

Koselleck, R. (1979). "Kriegergedenkmäle als Identitätsstiftungen der Überlebenden", Identität, Odo Marquard og Karlheinz Stierle (red.), W. Fink, München, s. 256-276

Koselleck, R. (1982). "Die Verzeitlichung der Utopie“, Utopieforschung, Wilhelm Vosskamp (red.), Metzler, Stuttgart, s. 1-14

Koselleck, R. (1988). Critique and Crisis. Enlightenment and the Pathogenesis of Modern Society, Berg, Oxford

Koselleck, R. (1998). "Die falsche Ungeduld", Die Zeit, nr. 13

Koselleck, R. (2000a) [opr. 1988]. "Erfahrungswandel und Methodenwechsel. Eine Historisch-antropologische Skizze“, Zeitschicbten. Studien zur Historik, , Suhrkamp, Frankfurt am Main, 2000, s. 75-77

Koselleck, R. (2000b) [opr. 1972]. "Über die Theoriebedürftigkeit der Geschichtswissenshaft“, Zeitschichten. Studien zur Historik, Suhrkamp, Frankfurt am Main, s. $298-316$

Koselleck, R. (2000c) [opr. 1975]. "Zur historisch-politischen Semantik asymmestrischer Gegenbegriffe“, Vergangene Zukunft. Zur Semantik, Geschichtlicher Zeiten, Suhrkamp, Frankfurt am Main, s. 211-259

Koselleck, R. (2000d) [opr. 1987]. "Historik und Hermeneutik“, Zeitschichten. Studien zur Historik, Suhrkamp, Frankfurt am Main, s. 97-119

Koselleck, R. (2003). "Formen der Bürgerlichkeit: Reinhart Koselleck im Gespräch mit 


\section{Niklas Olsen}

Manfred Hettling und Bernd Ulrich“, Mittelweg 36, Zeitschrift des Hamburger Instituts für Sozialforschung, 12. ig, s. 74-76

Kuhn, Helmut (1961). Anmeldelse af Kritik und Krise, Historische Zeitschrift, bd. 192, s. 665666

Laak, Dirk van (1993). Gespräche in der Sicherheit des Schweigens. Carl Schmitt in der politischen Geistesgeschichte in der frühen Bundesrepublik, Akademie Verlag, Siegburg

Mehring, Reinhard (udkommer 2005). "Begriffssoziologie, Begriffsgeschichte, Begriffspolitik. Zur Form der Ideengeschichtsschreibung nach Carl Schmitt und Reinhard Koselleck“, Formen der Ideengeschichte, Harald Bluhm (red.), Baden-Baden

Müller, Jan-Werner (2003). A Dangerous Mind: Carl Schmitt in Post-War European Thought, Yale University Press, London

Niethammer, Lutz (1993). Posthistoire: Has History come to an End, Verso, London

Olsen, Niklas (2004). "Af alle mine lærere har Schmitt været den vigtigste: Reinhart Kosellecks intellektuelle og personlige relationer til Carl Schmitt«, Historisk Tidsskrift, bd. 104, hf. 1, s. 30-60

Schmitt, Carl (1938). Der Leviathan in der Staatslehre des Thomas Hobbes: Sinn und Feblschlag eines politischen Symbol, Hanseatische Verlagsanstalt, Hamburg

Schmitt, Carl (1940) [opr. 1926]. “Zu Friedrich Meineckes 'Idee der Staatsräson', Positionen und Begriffe im Kampf mit Weimar - Genf - Versailles 1923-1939, Duncker \& Humblot, Berlin, s. 45-52 